\title{
Effect of Integrated Phosphorus Management on Yield, Nutrient Uptake of Soybean Grown on 'P' Deficient Soil
}

\author{
K.S. Dhadave*, R.V. Kulkarni, R.B. Pawar, D.S. Patil and G.G. Khot
}

Division of Soil Science and Agriculture Chemistry, College of Agriculture, Kolhapur, Mahatma Phule Krishi Vidhyapeeth, Rahuri, Maharashtra, India

*Corresponding author

\begin{abstract}
A B S T R A C T
The field experiment was conducted during Kharif 2017 at Post Graduate Research Farm,

\begin{tabular}{|l|}
\hline Key w ord s \\
Soybean, Phosphorus, \\
DAP, PMC \\
\hline Article Info \\
\hline Accepted: \\
10 October 2018 \\
Available Online: \\
10 November 2018 \\
\hline \hline
\end{tabular}

College of Agriculture Kolhapur with the view to study the effect of integrated phosphorus management for yield, nutrient uptake of soybean grown on "P" deficient soil. The soil of experimental site was slightly alkaline in reaction, low in available nitrogen, low in available phosphorus and very high in available potassium. The field experiment was carried out in randomized block design with three replications and seven treatments viz. absolute control $\left(\mathrm{T}_{1}\right)$, General recommended dose of fertilizer $\left(\mathrm{T}_{2}\right), 100 \% \mathrm{P}_{2} \mathrm{O}_{5}$ through PMC $\left(\mathrm{T}_{3}\right), 100 \% \mathrm{P}_{2} \mathrm{O}_{5}$ through DAP $\left(\mathrm{T}_{4}\right), 25 \% \mathrm{P}_{2} \mathrm{O}_{5}$ through PMC $+75 \% \mathrm{P}_{2} \mathrm{O}_{5}$ through DAP $\left(\mathrm{T}_{5}\right), 50 \% \mathrm{P}_{2} \mathrm{O}_{5}$ through PMC $+50 \% \mathrm{P}_{2} \mathrm{O}_{5}$ through DAP $\left(\mathrm{T}_{6}\right), 75 \% \mathrm{P}_{2} \mathrm{O}_{5}$ through PMC $+25 \% \mathrm{P}_{2} \mathrm{O}_{5}$ through DAP $\left(\mathrm{T}_{7}\right)$. The result indicated that the application of $25 \%$ $\mathrm{P}_{2} \mathrm{O}_{5}$ through PMC $+75 \% \mathrm{P}_{2} \mathrm{O}_{5}$ through DAP $\left(\mathrm{T}_{5}\right)$ recorded significantly higher plant height, number of branches per plant, number of grains per plant, number of pods per plant, yield, nutrient uptake and quality of soybean.
\end{abstract}

\section{Introduction}

Soybean (Glysine max (L.) Merill) a leguminous crop is one of the leading oil and protein containing crop of the world, it contains $40-44 \%$ protein, $20 \%$ oil, 3.3- 6.4 $\%$ ash and 24-26\% carbohydrate, besides, it also contains various vitamins and minerals. Soybean protein is rich in valuable amino acid lysine $(5 \%)$ and can be put to a number of uses. A large number of Indian and Western dishes such as bread, chappati, milk sweets, pastries, etc. can be prepared with soybean. Among grain legumes, it is an economically important crop that can be grown in diverse environments throughout the world. It is rich in minerals such as phosphorus, calcium and vitamins (Vitamins B, C and E). Its oil is used as a raw material in manufacturing of antibiotics, paints, adhesive, lubricants, etc. Soybean being richest, cheapest and easiest sources of best quality protein, fat and also having a vast multiplicity of uses as food and industrial product is sometimes called as "Wonder Crop".

It built up soil fertility by fixing large amount of atmospheric nitrogen through the root nodules and also through the leaf fall on the ground at maturity. 
In legumes, phosphorus stimulates rhizobial activity, nodule formation and thus helps in nitrogen fixation. It increases the water use efficiency, improves taste, storage quality and skin hardness. As phosphorus plays key role in photosynthesis, respiration, energy storage and transfer, cell division and enlargement, it has been shown to be important for growth development and yield of soybean (Katkar et al., 2002). Efficiency of ' $\mathrm{P}$ ' fertilizer throughout the world is around 10-25\% (Isherword, 1998), phosphatic fertilizers have low efficiency of utilization due to fixation in soil (Gaur, 1990) and poor solubility of native soil phosphorus, sometimes there is a build-up of insoluble phosphorus as a result of chemical phosphorus fixation (Dubey, 1997).

Root development, stack and stem strength, flower and seed formation of crop maturity and production, crop quality and resistance to plant diseases are the attributes associated with phosphorus nutrition. Phosphorus deficiency can limit nodulation in legumes and ' $\mathrm{P}$ ' fertilizer application can overcome the deficiency (Carsky et al., 2001).

Diammonium phosphate (DAP) is the world's widely used phosphorus fertilizer, containing $18 \% \mathrm{~N}$ and $46 \% \mathrm{P}_{2} \mathrm{O}_{5}$. Microorganisms play a key role in soil phosphorus availability to plant (Richardson, 2001). Press mud cake, a waste by product from sugar factories, is a soft spongy, amorphous and dark brown to brownish material containing sugar, coagulated colloids including cane wax, albuminoids, inorganic salt and soil particles. The press mud contains high percentage of organic carbon and it is a good source of organic matter, NPK and important micronutrients. It has established its importance in improving fertility, productivity and other physical properties of soil. The organic fraction of press mud cake contain 15$30 \%$ fiber, 5-15\% crude protein, 5-15\% sugar, 5-15\% crude wax and fat, 10-20\% ash comprising oxides of $\mathrm{Si}, \mathrm{Ca}, \mathrm{P}, \mathrm{Mg}$ and $\mathrm{K}$ (Diaz, 2016). This organic matter is highly soluble and readily available to the microbial activity in soil. In view of this, present investigation was undertaken on "Effect of integrated phosphorus management for yield, nutrient uptake of soybean grown on "P" deficient soil"

\section{Materials and Methods}

The experiment was conducted with seven treatments and three replication laid out in a randomized block design using soybean crop at Post Graduate Research Farm, College of Agriculture, Kolhapur, Maharashtra, India. The soil of the experiment site was sandy clay loam which was alkaline in reaction, low in available nitrogen $\left(163.04 \mathrm{~kg} \mathrm{ha}^{-1}\right)$, low in available phosphorus $\left(10.28 \mathrm{~kg} \mathrm{ha}^{-1}\right)$ and very high in available potassium $\left(285.6 \mathrm{~kg} \mathrm{ha}^{-1}\right)$. The treatments comprised of $\mathrm{T}_{1}$ : absolute control, $\mathrm{T}_{2}$ : General recommended dose of fertilizer, $\mathrm{T}_{3}: 100 \% \mathrm{P}_{2} \mathrm{O}_{5}$ through $\mathrm{PMC}, \mathrm{T}_{4}$ : $100 \% \mathrm{P}_{2} \mathrm{O}_{5}$ through DAP, $\mathrm{T}_{5}: 25 \% \mathrm{P}_{2} \mathrm{O}_{5}$ through $\mathrm{PMC}+75 \% \mathrm{P}_{2} \mathrm{O}_{5}$ through DAP, $\mathrm{T}_{6}$ : $50 \% \mathrm{P}_{2} \mathrm{O}_{5}$ through $\mathrm{PMC}+50 \% \mathrm{P}_{2} \mathrm{O}_{5}$ through DAP, $\mathrm{T}_{7}: 75 \% \mathrm{P}_{2} \mathrm{O}_{5}$ through $\mathrm{PMC}+25 \%$ $\mathrm{P}_{2} \mathrm{O}_{5}$ through DAP. The organic source of phosphorus was press mud cake and inorganic source was Diammonium sulphur. Rhizobium and PSB were used as seed treatment $\left(25 \mathrm{~g} \mathrm{~kg}^{-2}\right.$ seeds) for all treatments. $\mathrm{N}$ will be applied uniformly through urea to all treatments except control. At harvest, seed and straw yields were recorded. Plant samples were collected for chemical analysis of nitrogen, phosphorus, potassium in seed and straw samples. $\mathrm{N}$ was estimated by microkjeldahl method (Parkinson and Allen, 1975). For P and $\mathrm{K}$, plant samples were digested in a diacid mixture and $\mathrm{P}$ in the extract was determined by vanadomolybdate yellow colour method (Piper, 1966) and K was estimated by flame photometer method (Chapman and pratt, 1961). 


\section{Results and Discussion}

The data in Table 1 indicated that the plant height was found to be increased significantly due to integrated phosphorus management. The treatment $\mathrm{T}_{5}$ recorded significantly highest plant height $(83.38 \mathrm{~cm})$ but it was on par with $T_{2}, T_{4}, T_{6}$ and $T_{7}$. The treatment $T_{5}$ recorded significantly highest number of branches plant ${ }^{-1}(10.33)$ and it was on par with $\mathrm{T}_{4}$ and $\mathrm{T}_{6}$. The increase in plant height and number of branches plant ${ }^{-1}$ was due to integrated use of organic and inorganic phosphorus over control. These results were in confirmative with those reported by Maheshbabu et al., (2008) application of recommended dose of fertilizer (40:80:25 $\left.\mathrm{N}: \mathrm{P}: \mathrm{K} \mathrm{kg} \mathrm{ha}^{-1}\right)+$ FYM $5 \mathrm{t} \mathrm{ha}^{-1}$ in soybean recorded higher growth parameters, however it was at par with vermicompost $\left(4 \mathrm{tha}^{-1}\right)+$ rock phosphate $\left(176 \mathrm{~kg} \mathrm{ha}^{-1}\right)$

The number of pods plant ${ }^{-1}$ of soybean increased significantly due to integrated use of phosphorus sources viz. organic and inorganic. The highest number of pods plant ${ }^{-1}$ recorded in treatment $\mathrm{T}_{5}$ (77.67), however it was on par with $T_{2}$. The highest number of grains plant ${ }^{-1}$ was recorded in treatment $T_{5}$ (179.71). The all treatment showed increase in number of pods plant $^{-1}$ and number of grains plant ${ }^{-1}$ except control. The similar types of results were obtained by Koushal and Parbjeet (2011) the highest number of pods plant ${ }^{-1}(80.40)$ in the treatment where 50 per cent recommended $\mathrm{N}$ applied through urea +50 per cent $\mathrm{N}$ through FYM + PSB in soybean.

The grain and straw yield of soybean was increased significantly with the application of phosphorus in integrated manner through inorganic and organic sources. The significantly highest grain yield $\left(27.68 \mathrm{q} \mathrm{ha}^{-1}\right)$ and straw yield (37.73 q ha ${ }^{-1}$ ) was recorded in treatment $\mathrm{T}_{5}$ and it was on par with $\mathrm{T}_{2}$ and $\mathrm{T}_{4}$. The significantly highest grain and straw yield obtained due to application of $\mathrm{P}_{2} \mathrm{O}_{5}$ through 75 $\%$ DAP and $25 \%$ PMC. Because of use of phosphorus through organic and inorganic sources, there was proper supply of phosphorus throughout the growth stages of crop which might be probable reason. In case of grain and straw yield of soybean the all other treatments were superior over control. Jadhav et al., (2011) reported that, application of NPK through 25 per cent organic +75 per cent inorganic sources recorded the highest soybean grain yield $\left(26.39 \mathrm{q} \mathrm{ha}^{-1}\right)$ and straw yield $\left(15.09 \mathrm{q} \mathrm{ha}^{-1}\right)$ in integrated nutrient management.

The data in Table 2 indicated that the per cent $\mathrm{N}, \mathrm{P}$ and $\mathrm{K}$ content of soybean increased due to integrated nutrient management of phosphorus through organic and inorganic sources. The highest $\mathrm{N}$ content recorded in grain was $7.00 \%$ and in straw $0.51 \%$ and in case of $\mathrm{P}$ content in grain was $0.55 \%$ and in straw $0.23 \%$ as well as $\mathrm{K}$ content recorded in grain was $1.62 \%$ and in straw $1.50 \%$.

There was no significant effect of integrated nutrient management of phosphorus on nutrient concentration in grain and straw of soybean. Similar results obtained were corroborating with those reported by Devi et al., (2012) and Dhage et al., (2014).

The per cent N, P and $\mathrm{K}$ content of soybean increased due to integrated nutrient management of phosphorus through organic and inorganic sources. The highest $\mathrm{N}$ content recorded in grain was $7.00 \%$ and in straw $0.51 \%$ and in case of $\mathrm{P}$ content in grain was $0.55 \%$ and in straw $0.23 \%$ as well as $\mathrm{K}$ content recorded in grain was $1.62 \%$ and in straw $1.50 \%$. There was no significant effect of integrated nutrient management of phosphorus on nutrient concentration in grain and straw of soybean. Similar results obtained were corroborating with those reported by Devi et al., (2012) and Dhage et al., (2014). 
Table.1 Effect of integrated phosphorus management on growth and yield attributing characters and yield of soybean

\begin{tabular}{|c|c|c|c|c|c|c|}
\hline Treatments & $\begin{array}{c}\text { Plant } \\
\text { height } \\
\text { (cm) }\end{array}$ & $\begin{array}{c}\text { Number } \\
\text { of } \\
\text { branches }^{-1} \\
\text { plant }^{-1}\end{array}$ & $\begin{array}{l}\text { Number } \\
\text { of pods } \\
\text { plant }^{-1}\end{array}$ & $\begin{array}{l}\text { Number } \\
\text { of grains } \\
\text { plant }^{-1}\end{array}$ & $\begin{array}{l}\text { Grain } \\
\text { yield } \\
\left(\mathbf{q} \text { ha }^{-1}\right)\end{array}$ & $\begin{array}{c}\text { Straw } \\
\text { yield } \\
\left(\mathbf{q} \mathbf{h a}^{-1}\right)\end{array}$ \\
\hline$T_{1}$ - Absolute control & 65.90 & 7.07 & 31.67 & 80.40 & 18.48 & 25.37 \\
\hline$T_{2}-$ GRDF & 76.55 & 9.33 & 72.37 & 140.35 & 24.54 & 34.87 \\
\hline $\mathrm{T}_{3}-100 \% \mathrm{P}_{2} \mathrm{O}_{5}$ through PMC & 68.73 & 8.20 & 41.95 & 83.60 & 20.66 & 29.90 \\
\hline $\mathrm{T}_{4}-100 \% \mathrm{P}_{2} \mathrm{O}_{5}$ through DAP & 76.44 & 9.73 & 68.13 & 131.47 & 25.36 & 34.97 \\
\hline $\mathrm{T}_{5}-25 \% \mathrm{PMC}+75 \% \mathrm{DAP}$ & 83.38 & 10.33 & 77.67 & 179.71 & 27.68 & 37.73 \\
\hline $\mathrm{T}_{6}-\mathbf{5 0} \% \mathrm{PMC}+\mathbf{5 0} \% \mathrm{DAP}$ & 74.13 & 9.67 & 63.80 & 102.73 & 23.37 & 32.79 \\
\hline $\mathrm{T}_{7}-75 \% \mathrm{PMC}+25 \% \mathrm{DAP}$ & 80.00 & 9.27 & 53.77 & 98.10 & 21.69 & 30.10 \\
\hline $\mathrm{SE} \pm$ & 3.46 & 0.23 & 1.74 & 8.04 & 1.02 & 1.51 \\
\hline CD at $5 \%$ & 10.65 & 0.71 & 5.35 & 24.76 & 3.15 & 4.66 \\
\hline
\end{tabular}

Table.2 Effect of integrated phosphorus management on per cent N, P and K content in grain and straw of soybean.

\begin{tabular}{|c|c|c|c|c|c|c|}
\hline \multirow[t]{2}{*}{ Treatments } & \multicolumn{2}{|c|}{ Total N (\%) } & \multicolumn{2}{|c|}{ Total P (\%) } & \multicolumn{2}{|c|}{ Total K (\%) } \\
\hline & Grain & Straw & Grain & Straw & Grain & Straw \\
\hline $\mathrm{T}_{1}$ - Absolute control & 6.83 & 0.46 & 0.51 & 0.21 & 1.50 & 1.48 \\
\hline $\begin{array}{l}\mathrm{T}_{2^{-}} \text {GRDF (General } \\
\text { Recommended Dose of Fertilizer) }\end{array}$ & 7.00 & 0.49 & 0.55 & 0.23 & 1.62 & 1.49 \\
\hline $\mathrm{T}_{3}-100 \% \mathrm{P}_{2} \mathrm{O}_{5}$ through PMC & 6.97 & 0.47 & 0.52 & 0.22 & 1.51 & 1.48 \\
\hline $\mathrm{T}_{4^{-}}-100 \% \mathrm{P}_{2} \mathrm{O}_{5}$ through DAP & 6.98 & 0.50 & 0.53 & 0.23 & 1.57 & 1.49 \\
\hline $\mathrm{T}_{5^{-}} 25 \% \mathrm{PMC}+75 \% \mathrm{DAP}$ & 6.99 & 0.51 & 0.55 & 0.23 & 1.60 & 1.50 \\
\hline $\mathrm{T}_{6}-50 \% \mathrm{PMC}+50 \% \mathrm{DAP}$ & 6.86 & 0.48 & 0.53 & 0.23 & 1.59 & 1.49 \\
\hline $\mathrm{T}_{7^{-}} 75 \% \mathrm{PMC}+25 \% \mathrm{DAP}$ & 6.89 & 0.47 & 0.52 & 0.22 & 1.55 & 1.48 \\
\hline $\mathrm{SE} \pm$ & 0.13 & 0.21 & 0.01 & 0.03 & 0.03 & 0.01 \\
\hline $\mathrm{CD}$ at $5 \%$ & NS & NS & NS & NS & NS & NS \\
\hline
\end{tabular}


Table.3 Effect of integrated phosphorus management on per cent NPK content in grain and straw of soybean

\begin{tabular}{|l|c|c|c|c|c|c|}
\multicolumn{1}{|c|}{ Treatments } & \multicolumn{2}{c|}{$\mathbf{N}$} & \multicolumn{2}{c|}{$\mathbf{P}$} \\
\hline & Grain & Straw & Grain & Straw & Grain & Straw \\
\hline $\mathrm{T}_{1}$ - Absolute control & 130.02 & 11.58 & 9.20 & 5.42 & 27.10 & 37.46 \\
\hline $\begin{array}{l}\mathrm{T}_{2}-\text { GRDF (General Recommended } \\
\text { Dose of Fertilizer) }\end{array}$ & 162.48 & 16.97 & 13.30 & 8.01 & 39.50 & 52.07 \\
\hline $\mathrm{T}_{3}-100 \% \mathrm{P}_{2} \mathrm{O}_{5}$ through PMC & & & & & & \\
\hline $\mathrm{T}_{4}-100 \% \mathrm{P}_{2} \mathrm{O}_{5}$ through DAP & 141.56 & 13.97 & 10.37 & 6.64 & 31.55 & 44.27 \\
\hline $\mathrm{T}_{5}-25 \% \mathrm{PMC}+75 \% \mathrm{DAP}$ & 171.82 & 17.50 & 13.19 & 7.86 & 40.86 & 52.10 \\
\hline $\mathrm{T}_{6}-50 \% \mathrm{PMC}+50 \% \mathrm{DAP}$ & 183.12 & 19.25 & 15.73 & 8.82 & 45.35 & 56.60 \\
\hline $\mathrm{T}_{7}-75 \% \mathrm{PMC}+25 \% \mathrm{DAP}$ & 165.66 & 15.62 & 12.83 & 7.45 & 35.65 & 48.83 \\
\hline $\mathrm{SE} \pm$ & 144.67 & 14.15 & 11.09 & 6.88 & 34.83 & 44.66 \\
\hline $\mathrm{CD}$ at 5\% & 3.37 & 0.73 & 0.51 & 0.37 & 1.49 & 2.36 \\
\hline
\end{tabular}

Table.4 Effect of integrated phosphorus management on total uptake of NPK $\left(\mathrm{kg} \mathrm{ha}^{-1}\right)$ and oil and protein content $(\%)$ in soybean

\begin{tabular}{|c|c|c|c|c|c|}
\hline Treatments & $\mathbf{N}$ & $\mathbf{P}$ & $\mathbf{K}$ & $\begin{array}{c}\text { Oil } \\
\text { content }\end{array}$ & $\begin{array}{l}\text { Protein } \\
\text { content }\end{array}$ \\
\hline $\mathrm{T}_{1}$ - Absolute control & 141.60 & 20.78 & 64.56 & 19.01 & 39.02 \\
\hline $\begin{array}{l}\mathrm{T}_{2} \text { - GRDF (General } \\
\text { Recommended Dose of Fertilizer) }\end{array}$ & 179.45 & 30.27 & 91.57 & 19.76 & 39.97 \\
\hline $\mathrm{T}_{3}-100 \% \mathrm{P}_{2} \mathrm{O}_{5}$ through PMC & 155.53 & 24.34 & 75.82 & 19.13 & 39.77 \\
\hline $\mathrm{T}_{4}-100 \% \mathrm{P}_{2} \mathrm{O}_{5}$ through DAP & 189.32 & 30.69 & 92.96 & 19.93 & 39.87 \\
\hline $\mathrm{T}_{5}-25 \% \mathrm{PMC}+75 \% \mathrm{DAP}$ & 202.37 & 34.98 & 101.96 & 19.95 & 39.90 \\
\hline $\mathrm{T}_{6}-50 \% \mathrm{PMC}+50 \% \mathrm{DAP}$ & 181.28 & 28.45 & 84.48 & 19.51 & 39.15 \\
\hline $\mathrm{T}_{7}-75 \% \mathrm{PMC}+25 \% \mathrm{DAP}$ & 158.82 & 25.24 & 79.49 & 19.33 & 39.37 \\
\hline SE \pm & 3.72 & 1.16 & 3.62 & 0.74 & 0.76 \\
\hline CD at $5 \%$ & 11.47 & 3.57 & 11.16 & NS & NS \\
\hline
\end{tabular}


The data in Table 3 indicated that the uptake for $\mathrm{N}, \mathrm{P}$ and $\mathrm{K}$ in grain and straw in soybean increased significantly due to integrated nutrient management of phosphorus through organic and inorganic sources. The significantly higher nitrogen uptake in grain $\left(183.12 \mathrm{~kg} \mathrm{ha}^{-1}\right)$ and in straw $\left(19.25 \mathrm{~kg} \mathrm{ha}^{-1}\right)$ was recorded in treatment $\mathrm{T}_{5}$, in case of $\mathrm{N}$ content in straw treatment $\mathrm{T}_{5}$ was on par with treatment $\mathrm{T}_{4}$. Significantly higher phosphorus uptake in grain $\left(15.73 \mathrm{~kg} \mathrm{ha}^{-1}\right)$ and in straw $\left(8.82 \mathrm{~kg} \mathrm{ha}^{-1}\right)$ was recorded in treatment $\mathrm{T}_{5}$, but $\mathrm{P}$ uptake in straw was highest in $\mathrm{T}_{5}$ and it was on par with treatment $T_{2}$ and $T_{4}$ and significantly higher potassium uptake from grain $\left(45.35 \mathrm{~kg} \mathrm{ha}^{-1}\right)$ and from straw $(56.60$ $\mathrm{kg} \mathrm{ha} \mathrm{h}^{-1}$ ) was recorded in treatment $\mathrm{T}_{5}$, however it was on par with treatment $\mathrm{T}_{4}$. The all other treatments were superior over control. It indicates that application of ' $\mathrm{P}$ ' through organic and inorganic sources seems to be beneficial for availability of NPK nutrient in soil as well as for uptake by plants.

The data in Table 4 indicated that the total uptake of NPK of soybean increased significantly due to integrated phosphorus management through organic and inorganic sources. The significantly higher nitrogen uptake (202.37 $\left.\mathrm{kg} \mathrm{ha}^{-1}\right)$, phosphorus uptake $\left(34.98 \mathrm{~kg} \mathrm{ha}^{-1}\right)$ and potassium uptake (101.96 $\mathrm{kg} \mathrm{ha}^{-1}$ ) was recorded in treatment $\mathrm{T}_{5}$. The potassium uptake highest in $\mathrm{T}_{5}$ but it was on par with treatment $T_{2}$ and $T_{4}$. Increase in uptake of NPK might be due to proper management of key element phosphorus through organic and inorganic sources which was responsible for release of phosphorus in early growth stages of crop. Virkar and Thumbare (2011) reported application of recommended dose of fertilizers + 5 t FYM + bio fertilizers to soybean recorded significantly higher total uptake of nitrogen (225.54 $\left.\mathrm{kg} \mathrm{ha}^{-1}\right)$, phosphorus (30.08 kg ha ${ }^{-1}$ ) and potassium $\left(93.30 \mathrm{~kg} \mathrm{ha}^{-1}\right)$ by seed and straw of soybean. Thakur et al., (2009) found that, the uptake of nitrogen (113.64 $\left.\mathrm{kg} \mathrm{ha}^{-1}\right)$, phosphorus $\left(9.38 \mathrm{~kg} \mathrm{ha}^{-1}\right.$ ) and potassium $\left(36.66 \mathrm{~kg} \mathrm{ha}^{-1}\right)$ in seed as well as total uptake of nitrogen (140.82 $\mathrm{kg} \mathrm{ha}^{-1}$ ), phosphorus $\left(13.28 \mathrm{~kg} \mathrm{ha}^{-1}\right)$ and potassium $\left(86.61 \mathrm{~kg} \mathrm{ha}^{-1}\right)$ was maximum with application of 75 per cent of recommended dose of fertilizer coupled with phospho-compost @ $3 \mathrm{t} \mathrm{ha}^{-1}$ and was significantly superior over all other treatments.

The data in Table 4 indicated that the oil content of soybean was affected nonsignificantly due to integrated phosphorus management through organic and inorganic sources and it was ranged between $19.01 \%$ and $19.95 \%$. The higher oil content (19.95 $\%$ ) was recorded in treatment $\mathrm{T}_{5}$. Jadhav et al., (2007) reported that in soybean grain, higher crude protein $(39.18 \%)$ and per cent oil content (19.54\%) was recorded with combine application of organic, inorganic and bio fertilizers. The protein content of soybean was not affected significantly due to integrated nutrient management of phosphorus through organic and inorganic sources and it was ranged between to $39.02 \%$ and $39.97 \%$. The highest protein content was recorded in treatment $\mathrm{T}_{2}(39.97 \%)$. These results were in close conformity with the findings reported by Khaim et al., (2013) that is application of $75 \%$ recommended dose of inorganic fertilizer $+1 \mathrm{tha}^{-1}$ poultry manure recorded higher protein and oil content in soybean than other treatments.

\section{References}

Carsky, R.J., Singh, B.B. and Oyewole, R. (2001) Contribution of early -season cowpea to late season maize in the savanna zone of West Africa. Biology of Agriculture Horticulture 18, 303-315.

Chapman, H.D. and Pratt, P.F. (1961) Method of analysis for soil, plant and water. 
University of California, Division of Agricultural Sciences, U.S.A. pp 21-23.

Daiz, P.M. (2016) Consequences of compost press mud as fertilizers. International Journal of Advances in Microbiology and Microbiological Research 1, 28-32.

Devi, K.N., Singh, L.N.K. Devi, T.S., Devi, H.N., Singh, T.B., Singh, K.K. and Singh, W.M. (2012) Response of soybean (Glycine $\max (\mathrm{L}$.$) Merill) to$ sources and levels of phosphorus. Journal of Agricultural Science 4, 97529760.

Dhage, S.J., Patil, V.D. and Patange, M.J. (2014) Effect of various levels of phosphorus and sulphur on yield, plant nutrient content, uptake and availability of nutrient at harvest stages of soybean [Glycine $\max$ (L)]. International Journal Current Microbial Applied Science 3, 833-844.

Dubey, S.K. (1997) Co-inoculation of phosphorus bacteria with Bradyrhizobium japonicum to increase phosphate availability to rainfed soybean in Vertisol. Journal of Indian Society of Soil Science 45, 506-509.

Gaur, A.C. (1990) Phosphorus solubilizing microorganisms as biofertilizers. Omega Scientific Publishers, New Delhi pp.63-90.

Isherword, K.F. (1998) Fertilizer use and environment. In $\mathrm{N}$. Ahmed and A. Hamid (eds.), Proc. Symp. Plant Nutrition Management for Sustainable Agricultural Growth, pp- 57-76.

Jadhav, V.T., Waghmode, R.S. and Mote, M.S. (2011) Effect of organic and inorganic sources of nutrients on yield, nutrient uptake, soil fertility and economics of soybean-wheat cropping system. Journal of Agriculture Research and Technology 36, 369-373.

Katkar, K.M., Tariq, M., Taj, F.H. and Nawab, K. (2002) Phosphorus use efficiency of soybean as affected by phosphorus application and inoculation. Pakistan Journal of Agronomy 1, 49-50.

Khaim, S., Chowdhury, M.A.H., and Saha, B.K. (2013) Organic and inorganic fertilization on the yield and quality of soybean. Journal of Bangladesh Agricultural University 11, 23-28.

Koushal, S. and Parbjeet, S. (2011) Effect of integrated use of fertilizer, FYM and biofertilizer on growth and yield performance on soybean (Glycine Max (L) Merill). Research Journal of Agricultural Science 43.

Maheshbabu, H.M., Hunje, R., Patil, B.N.K. and Babalad, H.B. (2008) Effect of organic manures on plant growth, seed yield and quality of soybean. Karnataka Journal of Agriculture Science 21, 219221.

Meena, B.S. and Sharma, D.D. (2005) Effect of phosphorus sources, solublizers and bio-chemicals. Indian Journal of Agriculture Research 43, 101-106.

Meena, S., Potdukhe, S.R. and Ghasolia, R.P. (2013) Effect of bio-fertilizers and FYM on phosphorus uptake by soybean [Glycine $\max$ (L.) Merrill] and residual $\mathrm{N}$ and $\mathrm{P}$ content in soil. An Asian Journal of Soil Science 8, 189-191.

Parkinson, J.A. and Allen, S.E. (1975) A wet oxidation procedure suitable for the determination of nitrogen and mineral nutrients in biological material. Communication Soil Science and Plant Analysis 6, 1-11.

Piper, C.S. (1966) Soil and plant analysis, Hans publisher Bombay, pp 135-136.

Ramesh, P., Panwar, N.R., Singh, A.B. and Ramana, S. (2009) Production potential, nutrient uptake, soil fertility and economics of soybean (Glycine max)wheat based cropping systems under organic, chemical and integrated nutrient management practices. Indian Journal of Agronomy 54, 278-83. 
Thakur, H.S., Raghuwanshi, S.R.H and Raghuwanshi, O.P.S. (2009) Integrated nutrient management in soybean (Glycine max (L) Merrill). Soybean Research 7, 16-20.

Virkar, A.T. and Thumbare, A.D. (2011) Effect of integrated nutrient management on growth and yield of soybean-wheat cropping sequence.
Journal of Agriculture Research and Technology 36, 358-363.

Waghmare, Y.M., Pawar, H.D. and Kalegore, N.K. (2011) Productivity and quality attributes of soybean (Glycine $\max (\mathrm{L}$.) Merill.) as influenced by bio-inoculants and farmyard manure under rainfed conditions. Journal of Agriculture Research and Technology 36, 427-429.

\section{How to cite this article:}

Dhadave, K.S., R.V. Kulkarni, R.B. Pawar, D.S. Patil and Khot, G.G. 2018. Effect of Integrated Phosphorus Management on Yield, Nutrient Uptake of Soybean Grown on 'P' Deficient Soil. Int.J.Curr.Microbiol.App.Sci. 7(11): 1033-1040.

doi: https://doi.org/10.20546/ijcmas.2018.711.119 